\title{
"Impact of trade liberalization on technical efficiency of mining sector: A case of selected SADC countries"
}

\begin{tabular}{|c|c|}
\hline AUTHORS & $\begin{array}{l}\text { Shylet Masunda (i) } \\
\text { Ireen Choga (iD) }\end{array}$ \\
\hline ARTICLE INFO & $\begin{array}{l}\text { Shylet Masunda and Ireen Choga (2021). Impact of trade liberalization on } \\
\text { technical efficiency of mining sector: A case of selected SADC countries. } \\
\text { Problems and Perspectives in Management, 19(4), 362-374. } \\
\text { doi:10.21511/ppm.19(4).2021.29 }\end{array}$ \\
\hline DOI & http://dx.doi.org/10.21511/ppm.19(4).2021.29 \\
\hline RELEASED ON & Wednesday, 08 December 2021 \\
\hline RECEIVED ON & Tuesday, 21 September 2021 \\
\hline ACCEPTED ON & Friday, 19 November 2021 \\
\hline LICENSE & $\begin{array}{l}(c) \text { EY } \\
\text { This work is licensed under a Creative Commons Attribution } 4.0 \text { International } \\
\text { License }\end{array}$ \\
\hline JOURNAL & "Problems and Perspectives in Management" \\
\hline ISSN PRINT & $1727-7051$ \\
\hline ISSN ONLINE & $1810-5467$ \\
\hline PUBLISHER & LLC "Consulting Publishing Company "Business Perspectives" \\
\hline FOUNDER & LLC "Consulting Publishing Company "Business Perspectives" \\
\hline
\end{tabular}

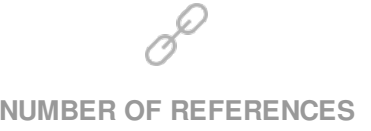

63

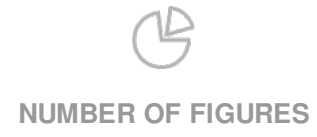

0
NUMBER OF TABLES

6

(C) The author(s) 2022. This publication is an open access article. 


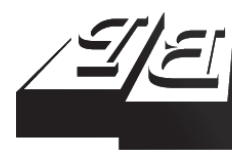

\section{BUSINESS PERSPECTIVES}

LLC "CPC "Business Perspectives" Hryhorii Skovoroda lane, 10, Sumy, 40022, Ukraine www.businessperspectives.org
Received on: $21^{\text {st }}$ of September, 2021 Accepted on: $19^{\text {th }}$ of November, 2021 Published on: $8^{\text {th }}$ of December, 2021

๑) Shylet Masunda, Ireen Choga, 2021

Shylet Masunda, Ph.D. in Economics, Lecturer, Great Zimbabwe University, Zimbabwe.

Ireen Choga, Ph.D., Associate Professor of Economics, School of Economic Sciences, North West University, South Africa. (Corresponding author)
IMPACT OF TRADE LIBERALIZATION ON TECHNICAL EFFICIENCY OF MINING SECTOR: A CASE OF SELECTED SADC COUNTRIES

\begin{abstract}
Productive inefficiency and lagging technology progress are major reasons behind the Southern Africa Development Community's (SADC) continued exportation of unprocessed minerals to the world markets. The study seeks to uncover the impact of trade openness on the technical efficiency of the mining sector in selected SADC countries (Botswana, DRC, Namibia, South Africa, Zambia, and Zimbabwe). Technical efficiency is the ability of any production process to produce maximum output from minimum quantities of inputs. A Cobb Douglas Stochastic Frontier Approach in a singlestage maximum likelihood estimation of Green's true fixed effects was used to compute technical efficiency (scores) and the technological progress in the mining sector of SADC. Results indicate that there is no technical efficiency gains from trade liberalization during the period under study together with positive and significant technological progress. A coefficient of 0.72 suggests that a $1 \%$ increase in trade openness increases technical inefficiency in the mining sector by $0.72 \%$. The parameter coefficient from the truncated normal distribution of the true fixed effects model indicated that technological progress from one year to the next year would lead to a $2.6 \%$ increase in the output index of the mining. Technological progress in the mining sector should target upstream mineral value chains instead of only upgrading technology in one dimension of extraction. In addition, countries should collectively and gradually put across laws that force new investments in the extraction of minerals to erect processing plants in mining value addition of host countries to re-direct economies into a growth path.
\end{abstract}

\section{Keywords}

mining efficiency, trade openness, Cobb Douglas Stochastic Frontier analysis, mining value addition

JEL Classification

L72, Q37, F18

\section{INTRODUCTION}

The study is founded on recent regional debates and efforts that are directed towards accelerating industrialization through value addition and beneficiation in the mining sector of SADC countries to strengthen their regional integration through the production of higher value chain tradable goods on the advantage of natural resources. SADC countries have been pursuing economic and legal regional frameworks such as the SADC Treaty, Regional Indicative Strategic Development Plan, SADC Protocol on Trade, Industrial Upgrading and Modernisation Programme, SADC Industrial Development Policy Framework, SADC Industrial Strategy and Road Map 2015-2063, and recently - the African Continental Free Trade Area (AfCFTA). The central challenge facing Africa is a paradigm shift from a market of raw minerals to a market of processed mineral-based goods (according to SADC Industrialization Strategy Road Map 2015-2063).

The study is motivated by the need to determine the nature of technological progress and technical efficiency in the sector and hence link 
trade liberalization. Africa, particularly SADC, is bestowed with useful minerals and mineral materials. There are vast reserves of platinum, manganese, gold, vanadium, diamonds, and chromite (African Union, 2009). If trade openness is a major facilitating agent of productivity growth in mining through its effect on technology spillovers, the study also questions the inability of this same technology transfer flow to forwarding linkages of the mining sector, as this would also boost mining value-added productivity. There is minimum mineral processing (forward linkages) within the SADC region and minerals are exported in raw and semi-finished form (World Bank, 2014). However, this region can realize increased returns from the export of value-added mining products, which could be a source for sustainable regional growth. As a result, the sector remains surrounded by very limited upstream and downstream linkages with the rest of the world. Is it poor technical efficiency leading to lack of mining forward linkages or trade openness failing to bring in the much-needed technological progress in the mining sector? The inquiry is crucial to SADC because mining production is a source of foreign exchange that directly contributes to economic development and growth.

Trade liberalization facilitates the dissemination of progressive technologies and technical expertise through two main channels. First, the local industry has a chance to secure innovative technologies and innovative production techniques through the importation of inputs, machinery, and equipment. In addition, competition and growing markets motivate industries to invest in new technology for higher quality (Grossman \& Helpman, 1991 cited in Saggi, 2002).

\section{LITERATURE REVIEW}

Productivity and growth are best explained by the exogenous and the endogenous growth models of Solow (1956), Rostow (1990), Romer (1994), Lucas (1988), Rebello (1991), Mankiw (1995), and Prescott (1997). The exogenous growth model alludes that capital accumulation drives productivity but eventually it succumbs to diminishing returns to a factor, and therefore long-run productivity growth is an exogenous technological progress phenomenon. Endogenous growth models denote that technology progress is an outcome of explicit and deliberate production activity. On the other hand, new growth models concur that long-run productivity growth is attained by either circumventing diminishing returns to scale or adopting internal technological progress (Stiroh, 2001). Technological progress is viewed differently in these theories, that is, either endogenously or exogenously determined, but they both establish that technological progress is key to the long-run and sustainable growth.

Technology gap theory focuses on the supply-side and explains the differences in national productivity as differences in technology stock (Elmslie \& Vieira, 2002). Posner's imitation lag model analyzed the effect of technology on trade. The process of technological change leads to an imitation gap which then influences the pattern of international trade. The technology gap is explained by differences in expenditure on research and development. The theory explains the imitation lag in main four lags: foreign reaction lag, domestic reaction lag, imitation lag, and demand lag. Foreign reaction lag is the time taken by the innovating firm to start producing a new product followed by domestic reaction lag - time taken by the domestic producer to follow the correct path and establish stable production systems in the domestic market. Imitation lag is the time required by local firms to get familiarized with new product production technologies and take them to the market.

The theory represents a significant portion of reality on the world markets. Technology is not similar across countries and ceases to be not a public good, according to Solow (1956), but rather a product which nations have to commit resources such as research and development to attain technology endogenously. The study agrees that continuous investment in research and development is the sustainable way of growing economies as being seen in industrial economies like China, Japan, the USA, Italy, etc. This implies maintaining their status of always leading in world markets, always working to catch up timeously with changing consumer preferences and tastes. To some extent, this paper is bound to doubt the predictions 
made by the theory in that technology diffusion has occurred truly in some sectors but not all sectors because minimum technology transfer is recorded in the mining sector that has seen much of further processing taking place in industrialized countries and thus lacking imitation.

Phuong (2018) examined Total Factor Productivity (TFP) growth, technological progress, and efficiency in the Vietnamese coal mining industry in a non-parametric approach for a period 2007-2013. TFP of Vietnam's coal mining declined because of slow technological progress and poor efficiency. It, therefore, meant that enhancing human resource training, technology, and research and development would improve efficiency and productivity. The study utilized Data Envelopment Analysis (DEAP) method to measure and separate total factor productivity into technical change and technical efficiency. Malmquist index was also used to measure productivity growth. The decomposition enabled the identification of benefits technological progress and efficiency are bringing to the growth of the coal sector. Results indicated that TFP of the coal industry declined due to technology regress and the study recommended that to improve productivity, there is a need for enhancement of qualifications of management, human capital development, strengthening of technological innovation, and implementation of better marketing activities to grow into virgin markets and maintain traditional markets. The study informs the current one on the decomposition of TFP growth using the DEA method. Splitting of the components of TFP would help in determining the contributions made by each towards mining productivity, which is the avenue to link productivity growth and the missing mining value addition in SADC.

Sahoo et al. (2017) investigated the output efficiency of the mining industry in India using Total Factor Productivity decomposition. They examined the TFP growth of the Indian mining industry from 1989 to 2014 based on the decomposed formulation of the stochastic production frontier. Productivity growth and its disintegrated components were matched over the study period. Results showed that TFP growth of the mining industry rose to $3.66 \%$ annually during $1989-2005$ and to $8.76 \%$ during 2006-2014. Decomposition results reflected that the key source of productivi- ty growth migrated from technological progress (TP) to technical efficiency (TE) change in current years. Recommendations for Indian mining sector suggest that it should concentrate on undertaking innovation and upgrading the present technology. The study utilized output and input data of 128 firms. Output was measured by the real mining output from 128 firms and inputs, labor (deflated number of days worked), capital (gross fixed capital using Perpetual Inventory Method (PIM)), and deflated power and fuel expenditure of mining firms. Since in Asian countries like India productivity in mining is enhanced by technical efficiency in recent years, this study aims to research this issue and provide pieces of advice.

Syed et al. (2015) analyzed the productivity growth in the mining sector in Australia at national, regional, and sector levels in the periods 1985-1986, 2009-2010, and 2010-2011. The study decomposed technology change into technological progress (TP), technical efficiency (TE), and scale efficiency (SE). The study utilized the Tornqvist index and a Translog stochastic frontier production. Results indicated that technological progress had negative (10.2\%) and technical efficiency (82.4\%) and scale efficiency $(27.8 \%)$ had positive meanings; TE and SE contributed positively and significantly to Australian mining ceteris paribus. Falling productivity in Australian mines increased prices of mining resources and that resulted in high profits, motivating extraction of deeper and lower grade ores. Since technological progress was negative, innovation and TP are key drivers of productivity growth over the long term.

Chu and Kalirajan (2010) examined the effect of trade openness on technical efficiency in the manufacturing firms of Vietnam in balanced panel data for the period 2000-2003. A stochastic-Translog production frontier and FRONTIER 4.1 were used to estimate the parameters. An inefficiency model was simultaneously estimated with frontier production following Battese and Coelli (1995) using a maximum likelihood estimator. Trade liberalization proxies were the effective rate of protection, the nominal rate of protection, and the import ratio. The results concluded that trade liberalization has a positive and confirmed impact on technical efficiency. Thus, trade liberalization is a tool to enforce competition on firms and chances for firms 
to be more productive to endure the competition in the bazaars.

Literature confirms a positive relationship between total factor productivity growth and trade liberalization in most parts of the world. However, the study observed that literature is biased towards some sectors like export-oriented manufacturing, service, and agriculture, or mining sector. Furthermore, limited researches have decomposed TFP into technological progress and technical efficiency and linked that to trade liberalization in the mining sector. The study took productivity growth to explain value addition. The paper aims to investigate the relationship between trade openness and technical efficiency that prevails in the SADC mining sector and ways of improving efficiency.

$H_{0}: \quad$ There are no technical efficiency and technology progress gains from trade openness in the mining sector of SADC.

\section{METHODOLOGY}

The study makes use of a time-varying technical inefficiency model by Battese and Coelli (1995) and Greene (2005 cited in Sunge \& Ngepha, 2020). That is disregarding Schmidt and Sickles (1984) whose models reflected that technical inefficiency does not change over time. Nevertheless, Kumbhakar (1990) and Battese and Coelli (1992) provided evidence that technical efficiency does change in the real world. In the real world, there are opportunities to learn new methods of production in mining in the face of market competition, government regulations, and international policy frameworks (Kumbhakar et al., 2015 cited in Sunge \& Ngepha, 2020). Panel data for the period 1980-2017 was used for selected SADC countries (Botswana, DRC, Namibia, South Africa, Zambia, and Zimbabwe). Total Factor Productivity was decomposed into technical change and technical efficiency, thus following Farrell (1957) and Aigner et al. (1977). The analysis of productivity is focused on the frontier of best practice production that measures and explains variations in Total Factor Productivity relative to the frontier and the amount by which TFP is less than the potential frontier. Thus, treating TFP as a technical change would misrepresent and misinform the idea, as TFP is a compound function. Estimation follows these steps, thus estimating the production function from which the study then derives the technical efficiency and technology change component. The technical efficiency component is then regressed on trade and other determinants simultaneously in a single-stage procedure.

\subsection{Cobb Douglas Stochastic Frontier using maximum likelihood estimator}

To predict the technical efficiency of industry, the first step in a one-stage procedure is to estimate a production function from which the study then derives the technical inefficiency component, which is built as shown in equation (1). Thus, the study confirms that besides inputs and stochastic noise (measurement errors, omission of variables in a vector of inputs, errors in choosing the function), technical efficiency plays a major role in improving productivity. Technical inefficiency may damage total factor productivity growth.

$$
\ln \left(y_{i t}\right)=\beta_{0}+\sum_{i=1}^{n} \beta_{i} \ln X_{i t}+v_{i t}-u_{i t},
$$

where $y_{i t}$ is the $i$ country's output (mining value addition); $X_{i t}$ is $i$ country's inputs; $\beta_{0}, \beta_{i}$, are parameters to be estimated and $i$ and $t$ represent country and time in years. The study used the mining value-added variable. Measuring technical efficiency scores will allow to identify the most efficient Decision-Making Unity (DMU) and assess those DMUs lagging. Hence, the paper investigates the relationship between trade openness and technical efficiency that prevails in SADC mining and ways of improving efficiency.

\subsection{Determinants of technical inefficiency model}

The study, therefore, agrees that besides inputs shown in equation (1), other exogenous factors can affect technical efficiency across industries, countries, and firms. A single-stage procedure that involves a simultaneous Maximum Likelihood Estimator regression on $z_{i t}$ - technical inefficiency regressors and all stochastic frontier parameters was done (Kumbhakar et al., 2015). A single-stage procedure is known to reduce bias 
as compared to a two-step procedure. One of the critical assumptions is that $v_{i t}$ and $u_{i t}$ are identically and independently distributed (iid) of each other and the regressors (Kumbhakar \& Lovell, 2000). The two-stage procedure has been proven to be misspecified (Battese \& Coelli, 1995) ${ }^{1}$ and inconsistent in assumptions about the distribution of inefficiencies. The study estimates time-varying technical inefficiency following Greene (2005) and Battese and Coelli (1995) mainly because the paper practically took the mining industry as the industry where efficiency cannot be fixed but rather it varies as technology and experience are gained over time and it is specific to a particular industry (heterogeneous).

Greene (2005) stochastic production frontier for single stage using MLE estimator is as follows:

$$
\begin{aligned}
& y_{i t}=f\left(x_{i t} ; \beta, T\right)+v_{i t}-\left(z_{i t} ; \delta+\omega_{i t}\right), \\
& T E_{i t}=\exp \left(-u_{i t}\right)=\exp -\left\{\left(z_{i t} ; \delta+\omega_{i t}\right)\right\},
\end{aligned}
$$

where $i=1,2 \ldots \ldots . N, t=1,2 \ldots . T$ and $y_{i t}$ output for the $i$ th firm at $t$ time; $x_{i t}$, is a vector of inputs associated with $i$ th firm and $\beta$ is the vector of inputs coefficients for the associated independent variables in the production function. $T$ captures technological progress between two periods and technical inefficiency model by:

$$
\mu_{i t}=z_{i t} \delta^{1}+\omega_{i t},
$$

where $z_{i t}$, is a vector $\left(\mathrm{M}^{\star} 1\right)$ made up of factors that affect firm efficiency /country $i$ at period $t$ and $\omega_{i t}$ is the error term and $\delta$ is a vector of parameters to be estimated. The parameters $\delta_{v}{ }^{2}$ and $\delta_{u}{ }^{2}$ are replaced with $\delta^{2}=\delta_{v}{ }^{2}+\delta_{u}{ }^{2}$ and $\lambda={ }_{v}=\delta_{u}{ }^{2} / \delta^{2}$ for estimation using the maximum likelihood method. If calculated values of lambda are close to zero it rules out the presence of inefficiency however near a unit (one), it predicts that the production technology is inefficient.

\subsection{Empirical framework}

The study adopted the findings of Díaz-Mayans and Sánchez-Pérez (2014) who focused on innovation, exports, and technical efficiency in Spain.
The empirical model of the one-step procedure is starting with the stochastic frontier framework:

$$
\begin{aligned}
& V A_{i t}=\beta_{0}+\beta_{1} \ln K_{i t}+\beta_{2} \ln L_{i t}+ \\
& +\theta_{1} D I N P_{i t}+\theta_{2} D I N P R_{i t}+\lambda_{t} T D_{t}+v_{i t}-u_{i},
\end{aligned}
$$

where $V A_{i t}$ value-added as the explained variable; $K_{i t}$ - capital stock, the value of machinery and equipment excluding grounds and buildings; $L_{i t}$ - total salaries and wages paid by the firm; TD time trend; DINP ${ }_{i t}$ - dummy that takes the value one if there is product innovation and zero otherwise product to capture the impact of innovative activities in the frontier; $D I N P R_{i t}$ - dummy that takes the value of one if there is process innovation; Dummy ${ }_{i t}$ - dummy to distinguish between sectors (that takes the value of one when the firm belongs to the corresponding sector of activities otherwise this value is zero).

Simultaneously, the inefficiency determinants were estimated and particular attention was given to the effect of exports on efficiency as other determinants included firm size, investment over the capital, and proportion of external funds over value-added. The determinants of the technical efficiency model are calculated by:

$$
u_{\mathrm{it}}=\delta_{0}+\delta_{1} \text {, }
$$

(exports, firm size, investment over capital, proportion of external funds over value-added) (DíazMayans \& Sánchez-Pérez, 2014).

The present study borrows the proposed models and modifies models by instead choosing to use a Cobb Douglas Stochastic Frontier model to investigate the effect of trade liberalization on technical efficiency in the mining sector estimate a stochastic frontier:

$$
\begin{aligned}
& \ln Y_{i t}=\beta_{0}+\beta_{k} \operatorname{LnK}_{i t}+\beta_{l} \operatorname{Ln} L_{i t}+ \\
& +\beta_{f} f d i_{i t}+\sum_{t} \lambda_{t} D_{t}+\left(v_{i t}-u_{i t}\right), \\
& \beta_{0}, \beta_{k}, \beta_{l}, \beta_{f}>0
\end{aligned}
$$

where $Y_{i t}$ - mining value added (USD); $K_{i t}$ - is the capital stock; $L_{i t}$ - labor (worked hours in the mines); $f d i_{i t}$ - foreign direct investment inflow proxying technology transfer, $D_{t}$ the time trend representing technical change.

1 For more information on technical inefficiency estimation address Jondrow et al. (1982). 
Simultaneously, the study hypothesized the determinants of inefficiency using findings of Battese and Coelli (1995) to estimate the effect of trade openness on technical inefficiency in the mining sector:

$$
\begin{aligned}
& \mu_{i t}=\delta_{0}+\delta_{1} \ln \text { Tradeopennes }_{i t}+ \\
& +\delta_{2} \text { governance }_{i t}+\omega_{i t} .
\end{aligned}
$$

The study further elaborates the model as:

$$
\begin{aligned}
& \mu_{i t}=\delta_{0}+\delta_{2} \ln T O_{i t}+\delta_{2} \ln G V N C_{i t}+ \\
& +\gamma_{1} D_{u m m y}+\omega_{i t}, \\
& \delta_{0}, \delta_{1}, \delta_{2}<0
\end{aligned}
$$

where $\mu_{i t}$ are the country's technical inefficiency scores, measured as a proportion of country i's actual output $Y_{i t}$ to its best frontier output; $X_{i t}^{\prime} \beta+v_{i t}$. These scores are generated during the estimation of the stochastic frontier model; $\gamma_{1}$ Dummy $_{i t}-$ capturing country heterogeneity.

\subsection{Estimation and diagnostic procedures}

If the model has been estimated using ML, the paper tests for the absence of technical inefficiency using the $\mathrm{Z}$ test or LR test, or Wald test. It was decided to choose the LR test.

According to Aigner et al. (1997), the log-likelihood function for the half-normal model is parameterized $\delta^{2}=\delta_{v}{ }^{2}+\delta_{u}{ }^{2}$ and $\lambda=\delta_{u}{ }^{2} / \delta^{2}$.

Thus,

$$
\begin{aligned}
& H_{0}: \quad \lambda=0, \text { there is no technical inefficiency effect, } \\
& \text { and deviations from the frontier are due to } \\
& \text { noise. }
\end{aligned}
$$

$H_{1}: \quad \lambda=\delta_{u}^{2} / \delta^{2}>0$, there is technical inefficiency.

\section{DATA DESCRIPTION AND SOURCES}

Data used in the study was pulled from various secondary statistical sources. Mining value added is the dependent variable in the stochastic frontier model. The mining value-added data is sourced from the World Bank. FDI as a percentage of GDP was sourced from the SADC statistical yearbooks and World Bank. Indicators like state capacity, accountability, and implementation of a regulatory framework to address economic, social, and environmental consequences of mining proxied by government effectiveness index were taken from the World Bank Governance Indicators. Trade openness is proxied by ratios of total imports plus exports to GDP as a percentage. Data is sourced from the United Nations database, SADC statistical yearbook, the World Bank, and UNCTAD. The proxy for labor input is the number of workers in the mining sectors of SADC countries. Data were sourced from the United Nations Development Indicators (UNDPI), SADC statistical yearbooks (SADC, 2011), country-specific data sources, international mining, and quarrying utility data portals. Lastly, the study used the value-added share split method share ${ }_{i t} V A=V A_{i t} / V A_{t}$ as weights and then multiplied these by aggregate nominal stock such that $k_{i t}=k_{t}$ share ${ }_{i t} V A$ where $V A_{t}$ - total value-added by specific industry and $k_{i t}$ - gross fixed capital formation (Gouma et al., 2018). Data sources include UNCTAD, SADC statistical yearbooks, Chamber of Mines portals, and UN data.

\section{RESULTS}

This section presents the results on the panel unit root tests, pre-estimation procedures, and the Cobb Douglas Stochastic Frontier true fixed effects and the technical inefficiency model check.

Table 1 displays the unit-roots tests for the sample data the study used to calculate the total factor productivity (dependent variable) using the Hicks-Moorsteen Index from DPIN software. The same data is used to analyze the technical efficiency levels in the mining sector of the sample. Hence, Table 1 shows that mining value added ( $\triangle$ LOGMVA), gross value added ( $\triangle$ LOGTVA), governance $(\triangle \mathrm{LOGGVNC})$, and labor $(\triangle \mathrm{LOGL})$ fail to reject the null hypothesis that panel contains unit roots in levels and they got stationary after first difference 1(1) and are statistically significant at $1 \%$. Whereas, gross fixed capital formation (LOGGFCF), labor (LOGL), trade openness (LOGTO), and foreign direct investment inflow (LOGFD) reject the null hypothesis that panels contain unit roots and are stationary in level $1(0)$ 
Table 1. Stationarity results of the LLC and IPS tests for key variables of the technical efficiency model

Source: Authors' computations using STATA 14.

\begin{tabular}{|c|c|c|c|c|c|c|}
\hline \multirow{2}{*}{ Variable } & \multicolumn{3}{|c|}{ Trend and intercept with panel mean included } & \multicolumn{3}{|c|}{ Intercept and no trend with panel mean included } \\
\hline & Test & Statistics & P-Value & Statistics & P-value & Order of integration \\
\hline \multirow{2}{*}{$\triangle$ LOGMVA } & LLC & -8.3783 & $0.0000^{*}$ & -10.7201 & $0.0000^{*}$ & 1(1) Stationary \\
\hline & IPS & -9.0515 & $0.0000 *$ & -10.5477 & $0.0000 *$ & 1(1) Stationary \\
\hline \multirow{2}{*}{ LOGGFCF } & LLC & -4.4117 & $0.0000 *$ & -3.5280 & $0.0002 *$ & 1(0) Stationary \\
\hline & IPS & -3.3183 & $0.0005^{*}$ & -3.4792 & $0.0003^{*}$ & 1(0) Stationary \\
\hline \multirow{2}{*}{$\triangle \mathrm{LOGTVA}$} & LLC & -7.5911 & $0.0000^{*}$ & -9.1481 & $0.0000^{*}$ & 1(1) Stationary \\
\hline & IPS & -7.4895 & $0.0000^{*}$ & -8.6617 & $0.0000^{*}$ & 1(1) Stationary \\
\hline \multirow{2}{*}{ LOGK } & LLC & -5.7276 & $0.0000 *$ & -3.3660 & $0.0004 *$ & 1(0) Stationary \\
\hline & IPS & -4.6339 & $0,0000^{*}$ & -3.5786 & $0.0002^{*}$ & 1(0) Stationary \\
\hline \multirow{2}{*}{$\Delta \mathrm{LOGL}$} & LLC & -8.8635 & $0.0000^{*}$ & -10.7125 & $0.0000^{*}$ & 1(1) Stationary \\
\hline & IPS & -8.9556 & $0.0000^{*}$ & -10.2382 & $0.0000^{*}$ & 1(1) Stationary \\
\hline \multirow{2}{*}{ LOGTO } & LLC & -3.5676 & $0.0002 *$ & -2.8326 & $0.0023 *$ & 1(0) Stationary \\
\hline & IPS & -2.3999 & $0.0082 *$ & -1.8941 & $0.0291^{*}$ & 1(0) Stationary \\
\hline \multirow{2}{*}{$\triangle \mathrm{LOGGVNC}$} & LLC & -13.6004 & $0.0000^{*}$ & -14.1486 & $0.0000^{*}$ & 1(1) Stationary \\
\hline & IPS & -13.5200 & $0.0000^{*}$ & -13.2491 & $0.0000^{*}$ & 1(1) Stationary \\
\hline \multirow{3}{*}{ LOGFD } & LLC & - & - & - & - & - \\
\hline & IPS & -5.0778 & $0.0000^{*}$ & -6.5104 & $0.0000^{*}$ & 1(0) Stationary \\
\hline & FISHER & -5.4986 & $0.0000^{*}$ & -7.0081 & $0.0000 *$ & 1(0) Stationary \\
\hline
\end{tabular}

Note: $*, * *$, and $* * *$ denote significance at $1 \%, 5 \%$, and $10 \%$ respectively.

and statistically significant at less than $5 \%$. Hence, the study concludes that variables for the technical inefficiency model are stationary both in level and after the first difference.

\subsection{Generalized likelihood ratio test}

The selection of the appropriate model is also based on the likelihood ratio test, which is defined by LR statistics.

Table 2. Hypothesis testing to ascertain technical inefficiency in the model

Source: Author's computation from STATA.

\begin{tabular}{c|c|c|c|c}
\hline $\begin{array}{c}\text { Null } \\
\text { hypothesis }\end{array}$ & Restricted & Unrestricted & LR test & Decision \\
\hline $\begin{array}{l}H_{0}=\text { SFA not } \\
\text { appropriate/ }\end{array}$ & -134.1874508 & 27.4693 & 323.312 & $\begin{array}{l}\text { Reject null } \\
\text { hypothesis }\end{array}$ \\
\hline
\end{tabular}

Table 3. Critical values

Source: Kodde and Palm (1986).

\begin{tabular}{l|l|l|l|l|l|l|l}
\hline Df & .25 & .10 & .05 & .025 & .01 & .005 & .001 \\
\hline
\end{tabular}

\begin{tabular}{l|l|l|l|l|l|l|l|l|l|l|l}
6 & 7.257 & 9.998 & 11.911 & 13.742 & 16.074 & 17.791 & 21.666 \\
\hline
\end{tabular}

Results in Table 2 and Table 3 show that the LR test statistic is greater than the critical value from Kodde and Palm (1986), meaning $323.31>16.07$ thus concluding rejection of the null hypothesis at a $1 \%$ level of significance. Stochastic frontier is inappropriate or rather rejecting null of no technical inefficiency in the model. This implies that there are technical inefficiencies in the mining sector of SADC and hence further investigations will explore the levels and the determinants of technical inefficiency.

Table 4. Log-likelihood ratio test - selecting SFA versus OLS model

Source: Kodde and Palm (1986)

\begin{tabular}{|c|c|c|c|c|c|}
\hline $\begin{array}{c}\text { Null } \\
\text { hypothesis }\end{array}$ & $\begin{array}{c}\text { LR } \\
\text { values }\end{array}$ & $\begin{array}{l}\text { Critical } \\
\text { values }\end{array}$ & $\begin{array}{l}\text { Degrees } \\
\text { of } \\
\text { freedom }\end{array}$ & P-value & Decision \\
\hline $\begin{array}{l}\text { Functional form } \\
\text { (OLS versus SFA } \\
\left.H_{0}: \lambda=0\right)\end{array}$ & 27.4693 & 16.074 & 6 & 0.000 & Reject $H_{0}$ \\
\hline
\end{tabular}

Table 4 shows the results of the log-likelihood test and the study rejects the null hypothesis that Cobb Douglas Ordinary Least Squares be used as the functional form and accept the alternative that the Cobb Douglas Stochastic Frontier modeling is appropriate. Again, the study also crosschecked the results with parameterized log-likelihood function for half normal model $\delta^{2}=\delta_{v}{ }^{2}+\delta_{u}{ }^{2}$ and $\lambda=\delta_{u}^{2} / \delta^{2}$ and the half-normal true fixed effect according to Aigner et al. (1997). The study calculated the lambda value $=0.930344$. The statistic must be close to one meaning that variations in the output are a result of technical inefficiency. In the study, technical inefficiency accounts for $93 \%$ 
variation in output which is very high and thus strongly justifies the use of a stochastic frontier model. Therefore, using the three justifications given here, the paper can confidently use a Cobb Douglas Stochastic Frontier modeling to estimate technical efficiency in the mining sector of SADC.

Table 5. Cobb-Douglas Stochastic Frontier true fixed effects - maximum likelihood estimates

Source: Authors' computation using STATA 14.

\begin{tabular}{|c|c|c|c|}
\hline Variable & $\begin{array}{c}\text { Model I } \\
\text { half normal }\end{array}$ & $\begin{array}{c}\text { Model } 2 \\
\text { Exponential }\end{array}$ & $\begin{array}{c}\text { Model } 3 \\
\text { truncated } \\
\text { normal }\end{array}$ \\
\hline \multicolumn{4}{|c|}{ Dependent variable: Log mining value-added } \\
\hline LOGK & $\begin{array}{c}0.425^{*} \\
(.0305355)\end{array}$ & $\begin{array}{l}.4567668^{*} \\
(.0291594)\end{array}$ & $\begin{array}{l}.3995096^{*} \\
(.0395856)\end{array}$ \\
\hline LOGL & $\begin{array}{l}.1117902 * \\
(.0493475)\end{array}$ & $\begin{array}{l}.1019303^{*} \\
(.0382839)\end{array}$ & $\begin{array}{l}.1498464^{*} \\
(.0328752)\end{array}$ \\
\hline FDI & $\begin{array}{l}.0095396 \\
(.0092992)\end{array}$ & $\begin{array}{l}.0046653 \\
(.0076304)\end{array}$ & $\begin{array}{l}.0151626^{*} \\
(.0074762)\end{array}$ \\
\hline YEAR & $\begin{array}{l}.0182227^{*} \\
(.0035554)\end{array}$ & $\begin{array}{l}.018592 * \\
(.00307)\end{array}$ & $\begin{array}{l}.0260638 * \\
(.0034839)\end{array}$ \\
\hline$\sigma_{u}$ & $\begin{array}{l}.4433422 * \\
(.037527)\end{array}$ & $\begin{array}{l}.2787717^{*} \\
(.0275048)\end{array}$ & $\begin{array}{c}.6169053^{*} \\
(.1290543)\end{array}$ \\
\hline$\sigma_{v}$ & $\begin{array}{l}.1213104^{*} \\
(.0240144)\end{array}$ & $\begin{array}{l}.1123493^{*} \\
(.0153695)\end{array}$ & $\begin{array}{c}.1012782 * \\
(.01981)\end{array}$ \\
\hline \multicolumn{4}{|c|}{ Diagnostics } \\
\hline Obs. & 196 & 196 & 196 \\
\hline Wald $\chi^{2}$ & 985.01 & 1491.87 & 2018.33 \\
\hline Prob. $>\chi^{2}$ & 0.0000 & $0.0000^{*}$ & $0.0000^{*}$ \\
\hline$L-L$ & -25.9729 & -12.1585 & 27.4693 \\
\hline
\end{tabular}

Note: $* * *, * *$, and $*$ imply significance levels at the $10 \%, 5 \%$, and $1 \%$ levels, respectively. The value inside the parentheses is the corresponding standard error.

Table 6. Determinants of technical inefficiency

Source: Authors' computation using STATA 14.

\begin{tabular}{|c|c|c|c|c|}
\hline $\begin{array}{c}\text { Technical } \\
\text { inefficiency }\end{array}$ & Variable & Parameter & $\begin{array}{c}\text { Standard } \\
\text { error }\end{array}$ & Probability \\
\hline \multirow{6}{*}{$(\mu)$} & LOGTO & 0.7223404 & 0.14647 & $0.000 * * *$ \\
\hline & LOGGVNC & -1.056722 & 0.3218603 & $0.001^{* * *}$ \\
\hline & D2 & -2.168101 & 0.8179534 & $0.008^{* * *}$ \\
\hline & D3 & -3.586377 & 3.846671 & 0.351 \\
\hline & D4 & -4.891724 & 5.254606 & 0.352 \\
\hline & D6 & -0.4867863 & 0.4310747 & 0.259 \\
\hline
\end{tabular}

Note: $* * *, * *$, and $*$ imply significance levels at the $1 \%, 5 \%$ and $10 \%$ levels, respectively.

\section{DISCUSSION}

Table 5 shows the three-frontier model under different distribution functions documenting that factor inputs are positive and statistically significant except for FDI, which fails to be significant when exponential (ex) and half normal (hn) distribution is used. A $1 \%$ increase in capital (LOGK) would increase mineral production in SADC under this period by $0.43 \%, 0.46 \%$, and $0.40 \%$. That is in a half normal, exponential, and truncated normal (tn) distribution assumption, respectively, thus confirming conventional theories of productivity. Again, the coefficient of labor (LOGL) is positive and statistically significant, such that a $1 \%$ increase in factor labor would boost mining productivity by $0.11 \%, 0.10 \%$, and $0.14 \%$ under $h$, ex, and tn, respectively. Both factors are crucial in mining production evidenced by a significant percentage contribution from each factor. Capital (LOGK) has a higher percentage contribution to production, which possibly can support the need for capital deepening and sustainable human capital development in the mining sector. This finding supports the results of Ali and Hamid (1996) and Sato and Mitchell (1989) who concluded that capital is a key booster in the growth of production and value-added. In other words, the study can ascertain low productivity from labor to gradual reduction of labor as an input in the mining sector or declining investment in human capital development. Thus, policymakers in selected SADC countries need to invest in labor productivity.

The coefficient of net foreign direct investment inflow (FDI) proxying technology transfer is positive and only significant under truncated normal distributional assumption hence a 1-unit increase in FDI would increase productivity in mining by $1.52 \%$. Literature confirms that FDI is a pure input factor that can augment domestic capital as predicted by the Neoclassicals and from the endogenous growth perspective through technology transfer and knowledge spillovers. In Africa, FDI to extractive minerals has been positively correlated to productivity in the mining sector and other industries (Romer, 1994; Iddrisu et al., 2015; Tondl \& Fornero, 2008). However, a 1.52\% magnitude contribution in productivity is very moderate, which suggests the need to constantly attract new and value-added activities of FDI as well as review SADC mining policy that targets value addition in the mining sector.

Technological progress and technical efficiency are two different concepts that can either move in converging or diverging directions and apparently 
results do not converge. The study can certainly confirm that during the period from 1990 to 2017 there was a positive and significant association with the technology progress and mining production. The parameter coefficient from the truncated normal distribution true fixed effects model indicated that for the years under study consecutively an average of $2.6 \%$ increase in the output index was recorded in the mining sector in SADC ceteris paribus. The paper concludes that in the mining sector there has been a steady movement upwards of the production frontier, pointing to advancement in technology embodied in the capital. Interestingly, the region never experienced a technical regress, which probably could have worsened the mining progress in SADC. Technological progress enhances technical efficiency and consequently improves mining value addition through a reduction of cost of production and extending that into further processing of raw minerals. Similar results are documented by Ali and Hamid (1996), Parameswaran (2002), Jajri and Ismail (2006), and Abegaz (2013). They concur that technical change is an important ingredient of value addition.

Table 6 shows exogenous variables that determine technical (in)efficiency in the mining sector and dummies are capturing the country heterogeneity. The study investigated the link between trade openness and government effectiveness (governance) on technical efficiency in the mining sector of selected SADC countries. The coefficient of trade openness (LOGTO) is positive and statistically significant at a $1 \%$ level, such that a coefficient of 0.72 suggests that a $1 \%$ increase in trade openness increases technical inefficiency in the mining sector by $0.72 \%$. On the traditional theoretical background, the paper expected a robust positive link between trade orientation variable to technical efficiency. This suggests that there are no technical efficiency gains received through international trading in the mining sector. The results reiterate that productivity growth is measured by two mutually exclusive parts: technological progress (TC) and technical efficiency (TE); there is no evidence in the literature of systematic theories linking trade liberalization to technical efficiency (Rodrick, 1992 cited in Tybout, 1992). Hence, trade liberalization may fail to positively influence technical efficiency in the mining sector. Interestingly, the study found that there was technological pro- gress during this same period when the technical efficiency was negative. This implies that technological progress in the mining sector is vital to productivity growth and as such broadening of this technological progress to encompass forward linkages (processing) in the mining sector is a primary goal for SADC. Therefore, productivity gains reported in the main model are credited to technological progress rather than technical efficiency. Traditionally, trade openness does not affect negative technical change but rather results in either a positive or negative effect on technical efficiency (Iyer et al., 2008 cited in Djokoto, 2013). The same results are commonly found in the agriculture sector, construction, transport, and manufacturing (Oczkowski \& Sharma, 2005; Miljkovic \& Shaik, 2010; Djokoto, 2013; Miljkovic et al., 2013).

The study argues that exports from the mining sector are usually unprocessed raw minerals that fetch very low prices on the international market. This reality takes away the center of attention on improving production processes and as such exports of minerals are boosted only to achieve revenue targets rather than a desire to compete internationally through value addition and beneficiation. Hence, the study ascertains the limited mineral value addition productivity in the region to the gap between the technological progress and technical efficiency emanating from the failure of trade openness to bring in the much-needed technology transfer, adoption, and mastery of technology ceteris paribus. The findings conclude that technical efficiency cannot be improved by trade liberalizing in the mining industry but probably by adopting the best mining methods and sustainable technical capacity.

Governance (LOGGVNC) is proxied by the governmental effectiveness that is measured by the quality of public services, the capacity of civil service, independence from political pressure, and quality of policy formulation (Zhuang et al., 2010, p. 8). Due to the high correlation among the most six world bank governance indicators, the study hence chooses to use one indicator. The results indicated that good governance would reduce inefficiency in the mining industry by $1.06 \%$. Thus, a $1 \%$ increase in government effectiveness would reduce inefficiency by $1.06 \%$ at a $1 \%$ significance 
level. It can be concluded that improved quality of policy formulation promoted foreign direct investment initiatives, and as such aided the efficiency in the mining sector. Similar findings are shown by Fayissa and Nsiah (2013) and Rafayet et al. (2017), who approve of the positive impact of good governance on different facets of the econo- my. This is also emphasized in the African Mining Vision: promoting good governance of the mineral sector through transparency and participatory governance would work great to unlock complex linkages at all levels and enable mineral-endowed countries to achieve sustainable socio-economic growth paths.

\section{CONCLUSIONS}

The paper seeks to determine the link that exists between trade openness and technical efficiency and also to ascertain the presence of technology change in the mining sector of SADC. The key findings are that trade openness positively affects mining technical inefficiency meaning trade openness increases inefficiency in mining production by $0.72 \%$. The study concludes that there are no technical efficiency gains recouped from trade liberalization. Nevertheless, technological progress of $2.6 \%$ was positive and statistically significant, implying that total factor productivity change in the mining industry is credited to technological progress and good governance and not trade openness. Instead, technological progress can coexist with deteriorating technical inefficiency. This means that the mining sector failed to catch up with technology change that was instigated by trade openness. The result is not surprising since the mining sector of SADC and perhaps Africa is known as an imperfect competition market structure. The study recommends that technology progress in the mining sector should target upstream mineral value chains instead of only upgrading technology in one dimension of extraction. In addition, it is recommended that countries should collectively and gradually put across laws that force new investments in the extraction of minerals to erect processing plants in mining value addition of host countries as that could re-direct economies into a growth path. The emphasis is on major investors, multinational mining companies, that have well-established supply chains in the world markets and are leaders in innovation to spearhead mining processing in host countries. The study recommends frictionless entry and exit in the industry by investors as this would call more players in the mining sector and hence induce competition mood amongst giant players. To sustain technical efficiency, investment in human capital development allows mastery of technology and diffusion of best practice technology. Further investigations are expected to be targeted on mineral-specific productivity change to allow the designing of mineral-specific policies that may help improve mineral productivity and obtain a higher value.

\section{AUTHOR CONTRIBUTIONS}

Conceptualization: Shylet Masunda.

Data curation: Shylet Masunda.

Formal analysis: Shylet Masunda.

Funding acquisition: Ireen Choga.

Investigation: Shylet Masunda.

Methodology: Shylet Masunda.

Project administration: Ireen Choga.

Resources: Shylet Masunda.

Software: Shylet Masunda.

Supervision: Ireen Choga.

Validation: Shylet Masunda.

Visualization: Shylet Masunda.

Writing - original draft: Shylet Masunda.

Writing - review \& editing: Ireen Choga. 


\section{ACKNOWLEDGMENTS}

The authors are grateful to the North West University (RSA) for financing this study.

\section{REFERENCES}

1. Abegaz, M. T. (2013). Total factor productivity and technical efficiency in the Ethiopian manufacturing sector (Working Paper No. 010). Ethiopian Development Research Institute. Retrieved from https://ideas.repec. org/p/etd/wpaper/010.html

2. African Union. (2009). Africa Mining Vision. Retrieved from https://au.int/sites/default/files/ documents/30984-doc-africa mining_vision_english.pdf

3. Aigner, D., Lovell, C. A. K., \& Schmidt, P. (1977). Formulation and estimation of stochastic frontier production function models. Journal of Econometrics, 6(1), 21-37. https://doi. org/10.1016/0304-4076(77)900525

4. Ali, K., \& Hamid, A. (1996). Technical change, technical efficiency, and their impact on input demand in the agricultural and manufacturing sectors of Pakistan. The Pakistan Development Review, 35(3), 215228. Retrieved from https://www. pide.org.pk/pdf/PDR/1996/Volume3/215-228.pdf

5. Amos, T. T. (2007). An Analysis of Productivity and Technical Efficiency of Smallholder Cocoa Farmers in Nigeria. Journal of Social Sciences, 15(2), 127-133. https://doi.org/10.1080/09718923. 2007.11892573

6. Balakrishnan, P., \& Pushpangadan, K. (1994). Total FactorProductivity Growth in Manufacturing Industry: A Fresh Look. Economic and Political Weekly, 29(31), 2028-2035. Retrieved from https://www.jstor. org/stable/4401561

7. Battese, G. E., \& Coelli, T. J. (1988). Prediction of firm-level technical efficiencies with a generalized frontier production function and panel data. Journal of Econometrics, 38(3), 387-399. https://doi.org/10.1016/03044076(88)90053-X

8. Battese, G. E., \& Coelli, T. J. (1992). Frontier production functions, technical efficiency and panel data: With application to paddy farmers in India. Journal of Productivity Analysis, 3(1-2), 153-169. https://doi.org/10.1007/ BF00158774

9. Battese, G. E., \& Coelli, T. J. (1995). A model for technical inefficiency effects in a stochastic frontier production function for panel data. Empirical Economics, 20(2), 325-332. https://doi.org/10.1007/ BF01205442

10. Chu, S., \& Kalirajan, K. (2010). Impact of Trade Liberalization on Technical Efficiency of Vietnamese Manufacturing Firms. Conference on "Frontier Issues in Technology, Development and Environment". Madras School of Economics. Retrieved from http:// fgks.in/images/pdf/papers/118.pdf

11. Cornwell, C., Schmidt, P., \& Sickles, R. C. (1990). Production frontiers with cross-sectional and time-series variation in efficiency levels. Journal of Econometrics, 46(1-2), 185-200. https://doi. org/10.1016/0304-4076(90)90054W

12. Davis, A. G. (2010). Trade in mineral resources (Staff Working Paper ERSD-2010-01). World Trade Organization. Retrieved from https://www.wto.org/english/ res_e/reser_e/ersd201001_e.pdf

13. Díaz-Mayans, M. Á., \& SánchezPérez, R. (2014). Innovation, exports and technical efficiency in Spain (MPRA Paper No. 53230). Retrieved from https://mpra. ub.uni-muenchen.de/53230/

14. Djokoto, J. G. (2013). Trade Openness and Technical Efficiency Change in Ghana's Agriculture.
Journal of Empirical Economics, 1(1), 1-10. Retrieved from https:// www.academia.edu/5092658/ Trade_Openness_and_Technical_Efficiency_Change_in_Ghanas_Agriculture

15. Elmslie, B., \& Vieira, F. (2002). A primer on technology gap theory and empirics. In Foundations of International Economics (pp. 258282). Routledge.

16. Farrell, J. M. (1957). The Measurement of Productive Efficiency. Journal of the Royal Statistical, 120(3), 253-290. https:// doi.org/10.2307/2343100

17. Fayissa, B., \& Nsiah, C. (2013). The impact of governance on economic growth in Africa. Journal of Developing Areas, 47(1), 91-108. https://doi.org/10.1353/ jda.2013.0009

18. Gouma, R., Chen, W., Woltjer, P., \& Timmer, M. (2018). WIOD Socio-Economic Accounts 2016: Sources and Methods. World Input-Output Database Project. Retrieved from http://www.wiod. org/protected3/data16/SEA/ SEA16_Sources.pdf

19. Greene, W. (2005). Fixed and Random Effects in Stochastic Frontier Models. Journal of Productivity Analysis, 23(1), 7-32. Retrieved from http://www.jstor. org/stable/41770178

20. Grossman, G. M., \& Helpman, E. (1991). Quality Ladders in Theory of growth. The Review of Economics Studies, 58(1), 43-61. https://doi.org/10.2307/2298044

21. Hossain, M. K., Kamil A. A., Baten, M. A., \& Mustafa, A. (2012). Stochastic Frontier Approach and Data Envelopment Analysis to Total Factor Productivity and Efficiency Measurement of Bangladeshi Rice. PLoS ONE, 7(10), e46081. https://doi.org/10.1371/journal. pone. 0046081 
22. Iddrisu, A., Adam, B., \& Halidu, B. O. (2015). The Influence of Foreign Direct Investment (FDI) on the Productivity of the Industrial Sector in Ghana. International Journal of Academic Research in Accounting, Finance and Management Sciences, 5(3), 1-13. Retrieved from https:// hrmars.com/papers_submitted/1736/Article_01_The_Influence_of_Foreign_Direct_Investment.pdf

23. Iyer, K. G., Rambaldi, A. N., \& Tang, K. K. (2008). Efficiency externalities of trade and alternative forms of foreign investment in OECD countries. Journal of Applied Econometrics, 23(6), 749-766. https://doi.org/10.1002/jae.1024

24. Jajri, I., \& Ismail, R. (2006). Technical efficiency, technological change and total factor productivity growth in Malaysian manufacturing sector (MPRA Paper). Retrieved from https:// mpra.ub.uni-muenchen.de/1966/

25. Jondrow, J., Knox Lovell, C. A., Materov, I. S., \& Schmidt, P. (1982). On the estimation of technical inefficiency in the stochastic frontier production function model. Journal of Econometrics, 19(2-3), 233-238. https://doi.org/10.1016/03044076(82)90004-5

26. Kelle, W. (2002). Trade and the transmission of technology. Journal of Economic Growth, 7, 5-24. https://doi. org/10.1023/A:1013461025733

27. Kodde, D. A., \& Palm, F. (1986). Wald Criteria for Jointly Testing Equality and Inequality Restrictions. Econometrica, 54(5), 1243-1248. https://doi. org/10.2307/1912331

28. Kumbhakar, C. S., \& Knox Lovell, C. A. (2000). Stochastic Frontier Analysis. United Kingdom: Cambridge University Press. Retrieved from http:// catdir.loc.gov/catdir/samples/ cam032/99031297.pdf

29. Kumbhakar, S. C. (1990). Production frontiers, panel data, and time-varying technical inefficiency. Journal of
Econometrics, 46(1-2), 201-211. https://doi.org/10.1016/03044076(90)90055-X

30. Kumbhakar, S. C., \& Wang, H. J. (2005). Estimation of growth convergence using a stochastic production frontier approach. Economics Letters, 88(3), 300-305. https://doi.org/10.1016/j. econlet.2005.01.023

31. Kumbhakar, S. C., Wang, H.J., \& Horncastle, A. P. (2015). A Practitioner's Guide to Stochastic Frontier Analysis Using Stata. Cambridge University Press. https://doi.org/10.1017/ cbo9781139342070

32. Lucas, R. Jr. (1988). On the mechanism of economic development. Journal of Monetary Economics, 22(1), 3-42.

33. Mandal, S. K., \& Madheswaran, S. (2012). Productivity growth in Indian cement industry: A panel estimation of stochastic production frontier. The Journal of Developing Areas, 46(1), 287-303. Retrieved from http://www.jstor. org/stable/23215434

34. Mankiw, N. G., Phelps, E. S., \& Romer, P. M. (1995). The growth of nations. Brookings papers on economic activity, 1995(1), 275-326. https://doi. org/10.2307/2534576

35. Mankiw, G. N., Romer, D., \& Weil, D. N. (1992). A Contribution to the Empirics of Economic Growth. The Quarterly Journal of Economics, 107(2), 407-437. https://doi. org/10.2307/2118477

36. Miljkovic, D., \& Shaik, S. (2010). The Impact of Trade Openness on Technical Efficiency in U.S. Agriculture (Agribusiness \& Applied Economics Report No. 660). North Dakota State University. Retrieved from https:// www.researchgate.net/publication/254388758_The_Impact_of_ Trade_Openness_on_Technical_ Efficiency_in_US_Agriculture

37. Miljkovic, D., Miranda, S. H., \& Shaik, S. (2013). Trade openness and technical efficiency in Brazilian agriculture. Applied Economics Letters, 20(2), 103-106. https://doi.org/10.1080/13504851. 2012.684870
38. Oczkowski, E., \& Sharma, K. (2005). Determinants of efficiency in least developed countries: further evidence from Nepalese manufacturing firms. Journal of Development Studies, 41(4), 617-630. https://doi. org/10.1080/00220380500092721

39. Parameswaran, M. (2002). Economic reforms and technical efficiency: firm level evidence from selected industries in India (Working Paper No. 339). Retrieved from https://opendocs. ids.ac.uk/opendocs/bitstream/ handle/20.500.12413/3051/wp339. pdf? sequence $=1$

40. Phuong, V. H. (2018). Total Factor Productivity Growth, Technical Progress \& Efficiency Change in Vietnam Coal Industry Nonparametric Approach. E3S Web of Conferences, 35, 01009. https://doi.org/10.1051/e3sconf/20183501009

41. Prescott, C. E. (1997). Needed: A theory of Total Factor Productivity (Research Department Staff Report No. 242). Federal Reserve Bank of Minneapolis. Retrieved from https://www.minneapolisfed. org/research/sr/sr242.pdf

42. Rafayet, M. A., Erick, K., \& Bizuayehu, B. (2017). Government Effectiveness and Economic Growth. Economics Bulletin, 37(1), 222-227. Retrieved from http:// www.accessecon.com/Pubs/ EB/2017/Volume37/EB-17-V37I1-P21.pdf

43. Rebelo, S. (1991). Long-Run Policy Analysis and Long-Run Growth. The Journal of Political Economy, 99(3), 500-521. https:// doi.org/10.1086/261764

44. Rodrik, D. (1992). The limits of trade policy reform in developing countries. Journal of Economic Perspectives, 6(1), 87-105. https:// doi.org/10.1257/jep.6.1.87

45. Rodríguez, F., \& Rodrik, D. (2000). Trade Policy and Economic Growth: A Skeptic's Guide to the Cross-National Evidence (NBER Working Paper No. 7081). Cambridge, MA. https://doi. org/10.3386/w7081

46. Romer, P. M. (1994). The origins of Endogenous Growth. Journal of 
Economic Perspectives, 8(1), 3-22. Retrieved from https://www.jstor. org/stable/2138148

47. Rostow, W. W., \& Rostow, W. W. (1990). The stages of economic growth: A non-communist manifesto. Cambridge university press.

48. Saggi, K. (2002). Trade, Foreign Direct Investment, and International Technology Transfer: A Survey. The World Bank Research Observer, 17(2), 191-235. https://doi.org/10.1093/ wbro/17.2.191

49. Sahoo, A. K., Sahoo, D., \& Sahu, N. C. (2017). Productive performance of Indian Mining Industry: stochastic frontier decomposition. Global Journal of business, Economics and Management, 7(1), 80-88. https:// doi.org/10.18844/gjbem.v7i1.1469

50. Sato, R., \& Mitchell, T. (1989). The economics of technical progress. Eastern Economic Journal, 15(4), 309-336. Retrieved from https://www.jstor.org/stable/40326241

51. Schmidt, P., \& Sickles, R. C. (1984). Production frontier and panel data. Journal of Business and Economics Statistics, 2(4), 367-374. https://doi.org/10.2307/1391278

52. Schmidt, P., \& Wang, H. (2002). One-step and two-step estimation of the effects of exogenous variables on technical efficiency levels. Journal of Productivity Analysis, 18, 129-144. https://doi. org/10.1023/A:1016565719882

53. Southern African Development community (SADC). (2011). SADC statistics yearbook 2011. Retrieved from https://www.sadc. int/information-services/sadcstatistics/sadc-statiyearbook/

54. Solow, R. M. (1956). A contribution to the theory of economic growth. The quarterly journal of economics, 70(1), 65-94. https://doi.org/10.2307/1884513

55. Stiroh, K. J. (2001). What Drives Productivity Growth? Economic Policy Review, 7(1), 37-59. Retrieved from https://ssrn.com/ abstract $=844244$

56. Sunge, R., \& Ngepah, N. (2020). Agricultural trade liberalization, regional trade agreements and agricultural technical efficiency in Africa. Outlook on Agriculture, 49(1), 66-76. https://doi.org/ 10.1177\%2F0030727019870551

57. Syed, A., Grafton, R. Q., Kalirajan, K., \& Parham, D. (2015).

Multifactor productivity growth and the Australian mining sector. Australian Journal of Agricultural and Resource Economics, 59(4), 549-570. https://doi. org/10.1111/1467-8489.12122_

58. Tondl, G., \& Fornero, J. A. (2008). Sectoral productivity and spillover effects of FDI in Latin
America (FIW Working Paper No. 53). Retrieved from https:// www.fiw.ac.at/fileadmin/Documents/FOKO_II/TondlFornero. pdf

59. Tybout, J. R. (1992). Linking trade and productivity: New research directions. The World Bank Economic Review, 6(2), 189-211. Retrieved from https:// www.jstor.org/stable/3989854

60. United Nations Economic Commission for Africa. (2012a). Unleashing Africa's potential as a Pole of Global growth (Economic Report on Africa 2012)

Retrieved from https://reliefweb. int/sites/reliefweb.int/files/resources/ERA2012_ENG_FIN.pdf

61. United Nations Economic Commission for Africa. (2012b). African Development Forum (ADF-VIII). Retrieved from https://archive.uneca.org/adfviii/ pages/documents

62. World Bank. (2014). Diagnostic Trade Integration Study. Washingtion, DC: World Bank.

63. Zhuang, J., de Dios, E., \& Lagman-Martin, A. (2010). Governance and Institutional Quality and the Links with Economic Growth and Income Inequality: With Special Reference to Developing Asia (ADB Economics Working Paper Series No. 193). https://dx.doi. org/10.2139/ssrn.1619116 